Article

\title{
Biomimetic Water Oxidation Catalyzed by a Binuclear Ruthenium (IV) Nitrido-Chloride Complex with Lithium Counter-Cations
}

\author{
Zinaida M. Dzhabieva ${ }^{1}$, Gennady V. Shilov ${ }^{1}$, Lidia V. Avdeeva ${ }^{1, *}$, Vladislav V. Dobrygin ${ }^{2}$, \\ Virineya Yu. Tkachenko ${ }^{1,2}$ and Taimuraz S. Dzhabiev ${ }^{1, *}$ \\ 1 Institute of Problems of Chemical Physics of RAS, Moscow Region, Academician Semenov Ave., 1, \\ 142432 Chernogolovka, Russia; djabieva.zinaida@yandex.ru (Z.M.D.); genshil@icp.ac.ru (G.V.S.); \\ virineya_lam@mail.ru (V.Y.T.) \\ 2 Faculty of fundamental physical and chemical engineering, Lomonosov Moscow State University, GSP-1, \\ 1 Leninskiye Gory, 119991 Moscow, Russia; mr_phosgene@mail.ru \\ * Correspondence: TumanovaLV@yandex.ru (L.V.A.); timur@cat.icp.ac.ru (T.S.D.); \\ Tel.: +7-(49652)-2-18-94 (T.S.D.)
}

Received: 29 June 2019; Accepted: 26 December 2019; Published: 16 January 2020

\begin{abstract}
The lithium salt of the binuclear nitrido complex of ruthenium (IV) $\mathrm{Li}_{3}\left(\mathrm{Ru}_{2} \mathrm{NCl}_{8} \cdot 2 \mathrm{H}_{2} \mathrm{O}\right)$ was synthesized. Using UV spectroscopy and voltammetry, we studied complex behavior in aqueous solutions. It was found that in dilute solutions of this compound, $\mathrm{Cl}^{-}$ions are replaced by $\mathrm{H}_{2} \mathrm{O}$ molecules, and the intra-sphere redox reaction between $\mathrm{Ru}(\mathrm{IV})$ and $\mathrm{H}_{2} \mathrm{O}$, as well as the oxidation of water with the formation of oxygen and the acidic dissociation of coordinated water molecules also have been taking place. It was established by IR spectroscopy and ESI mass spectrometric analysis that not only the binuclear structure of the complex is preserved in acidic solutions, but also its dimerization product into the tetra-ruthenium dinitrido cluster $\mathrm{Ru}_{4} \mathrm{~N}_{2} \mathrm{O}_{5}{ }^{+}$, which is a catalyst for the water oxidation reaction. The activity of the catalyst was TOF $=0.33 \mathrm{~s}^{-1}, \mathrm{TON}=304$.
\end{abstract}

Keywords: biomimetic catalysis; water oxidation; oxygen; binuclear nitrido complex Ru(IV) with lithium counter-cations

\section{Introduction}

Green plants, algae, and some bacteria use water as a source of electrons in the process of photosynthesis to restore carbon dioxide into carbohydrates, resulting in the release of molecular oxygen. Water oxidation occurs in the coordination sphere of the manganese cofactor, which is associated with the polypeptide D1 of photosystem II (PSII), which according to the latest spectroscopic studies contains $4 \mathrm{Mn}$ atoms and one calcium atom and has a cubane-like structure (Figure 1) [1].

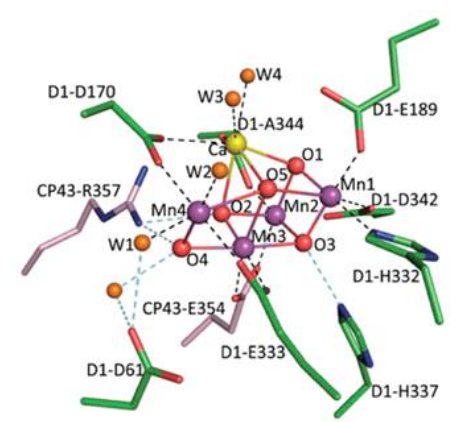

Figure 1. Structure of the manganese calcium cubane $\mathrm{Mn}_{4} \mathrm{Ca}$ and its ligand environment [1]. 
In the oxygenic photosynthesis (OPS) in the active center of PS II, four single-electronic oxidants-cation-radicals $\mathrm{P}_{680^{+}}$oxidize water according the reaction

$$
4 \mathrm{P}_{680}+2 \mathrm{H}_{2} \mathrm{O} \rightarrow 4 \mathrm{P} 680^{+\bullet}+\mathrm{O}_{2}+4 \mathrm{H}^{+} .
$$

Modeling the natural process of water oxidation (artificial photosynthesis (APS)) is one of the effective ways of storing solar energy [2,3]. The APS for photoinduced water decomposition uses the principles of chemical reactions involved in the OPS. Of course, the most adequate functional chemical models of PSII are $\mathrm{Mn}^{\mathrm{IV}} 2 \mathrm{~m}$ clusters [2,4,5]. However, in the biomimetic utilization of solar energy by means of photoinduced water decomposition, it is possible to use complexes of other transition metals: $\mathrm{Co}, \mathrm{Fe}, \mathrm{Ru}$, Ir, etc. In search of biomimetic catalysts, ruthenium analogues of Mn-co play an outstanding role because of the wide range of possible states of ruthenium oxidation, which allows for the implementation of some processes of transformation of substrates into reaction products that are unique in their mechanism and selectivity. Currently, more than 200 ruthenium complexes are known as water oxidation catalysts in the AP. Often, such catalysts have a small number of revolutions, and the total yield of $\mathrm{O}_{2}$ in such systems is small [6-10]. This is due to a number of disadvantages of such complexes: Low activity due to the presence of organic ligands in the complexes, which are oxidized faster than water; and low stability, due to the presence of labile bond Ru-O-Ru. The main directions of research in world science are connected with the variation of the ligand environment of different transition metals.

At present, quad-core complexes Ru with polyoxometallic (POM) ligands are of great interest. Ruthenium complexes were discovered several years ago and differed only by the nature of $\mathrm{X}$ cations surrounding the polyanion $\left(\left(\mathrm{Ru}_{4}(\mu-\mathrm{O})_{4}(\mu-\mathrm{OH})_{2}\left(\mathrm{H}_{2} \mathrm{O}\right)_{4}\right) \cdot\left(\gamma-\mathrm{SiW}_{10} \mathrm{O}_{36}\right)_{2}\right)^{10-}[11,12]$. These catalysts were immediately perceived by the scientific community as an important element in solving the problems of water oxidation in the APS [13-19]. The interest to them is connected with the fact that the volumetric nucleophilic $\mathrm{POM}$ ligands surrounding the adamantane-like core of ruthenium $\mathrm{Ru}_{4} \mathrm{O}_{6}$ or the quasi-linear core of $4 \mathrm{Co}$, protect the labile bonds Me-O-Me, preventing the complexes to collapse in the harsh conditions of water oxidation reactions. POM ligands are chemical inorganic models of the protein part of the holoenzyme. In addition to POM ligands, the counter-cations $\left(\mathrm{K}^{+}, \mathrm{Rb}^{+}\right.$, $\mathrm{Cs}^{+}, \mathrm{Li}^{+}$, etc.) surrounding the polyanionic nucleus also play a significant role in the activity and stability of catalysts. In early works, the structure and physical properties of the potassium salt of the binuclear nitrido complex were studied [20-22], which showed the possibility of synthesizing such a complex with lithium counter-cations, but no information was found on its use in the water oxidation reaction. Currently, only three works devoted to the water oxidation by $\mathrm{Ce}(\mathrm{IV})$ compounds catalyzed by ruthenium complexes with $\mathrm{Li}^{+}$counter-cations have been published. These complexes in an acidic environment are more active than similar complexes with other counter-cations [11,23,24].

Therefore, various approaches have been studied to increase the activity and stability of ruthenium catalysts:

1. Replacement of organic ligands in complexes with inorganic or POM ligands;

2. Replacement of $\mathrm{K}^{+}, \mathrm{Rb}^{+}$, and $\mathrm{Cs}^{+}$cations with the $\mathrm{Li}^{+}$counter-cation;

3. Replacement of the oxygen bridge between ruthenium nuclei with a nitrogen bridge.

Thus, the aim of the study is to implement the proposed approaches and to create an effective stable inorganic ruthenium catalyst of water oxidation in the coordination sphere of the tetra-nuclear ruthenium (IV) nitrido-chloride complex with $\mathrm{Li}$ + counter-cations, to characterize the complex by physico-chemical methods of analysis (X-ray diffraction analysis, IR and electronic spectroscopy, polarography, cyclic voltammetry, ESI mass spectrometric analysis and the kinetic method of investigation of the reaction of biomimetic water oxidation by $\mathrm{Ce}(\mathrm{IV})$ in the presence of binuclear complexes of ruthenium with N- and O-bridges, as well as assessment of their activity). 


\section{Materials and Methods}

As a functional model of the water enzyme in the OPS (i.e., enzyme: water:plastochinonoxidoreductase), the binuclear nitrido chloride ruthenium complex $\mathrm{Li}_{3}\left(\mathrm{Ru}_{2}(\mu-\mathrm{N}) \mathrm{Cl}_{8} \cdot 2 \mathrm{H}_{2} \mathrm{O}\right)$ was synthesized. Synthesis was performed using the method in Reference [25]. All operations were performed in air using commercial reagents (Fluka). The synthesis scheme is presented below.

\subsection{Synthesis Binuclear Ruthenium (IV) Nitrido Chloride Complex with Lithium Counter-Cations}

2.1.1. Production of Pentachloronitrosilruthenate $\mathrm{Li}_{2}\left(\mathrm{RuNOCl}_{5}\right) \cdot 2 \mathrm{H}_{2} \mathrm{O}$

$$
\begin{aligned}
& 2 \mathrm{RuCl}_{3}+6 \mathrm{LiNO}_{2}+6 \mathrm{HCl} \rightarrow 2 \mathrm{RuNOCl}_{3}+6 \mathrm{LiCl}+\mathrm{NO} \uparrow+3 \mathrm{NO}_{2}+3 \mathrm{H}_{2} \mathrm{O} \\
& 2 \mathrm{RuNOCl}_{3}+5 \mathrm{LiNO}_{2} \stackrel{\mathrm{H}_{2} \mathrm{O}}{\rightarrow} \mathrm{Li}_{2}\left(\mathrm{RuNO}\left(\mathrm{NO}_{2}\right)_{4} \mathrm{OH}\right)+3 \mathrm{LiCl}+\mathrm{HNO}_{2} \\
& \mathrm{Li}_{2}\left(\mathrm{RuNO}\left(\mathrm{NO}_{2}\right)_{4} \mathrm{OH}\right) \stackrel{\mathrm{HCl}}{\rightarrow} \mathrm{Li}_{2}\left(\mathrm{RuNOCl}_{5}\right) \cdot 2 \mathrm{H}_{2} \mathrm{O}
\end{aligned}
$$

$\mathrm{LiNO}_{2}(0.03471 \mathrm{M})$ was added to the warm solution of $\mathrm{RuCl}_{3}(0.01157 \mathrm{M})$ and $12.9 \mathrm{M} \mathrm{HCl}$ was added with constant mixing. After $\mathrm{NO}$ and $\mathrm{NO}_{2}$ were extracted, $\mathrm{LiNO}_{2}(0.02892 \mathrm{M})$ was added and $\mathrm{HCl}(12.9 \mathrm{M})$ was added, so the reaction was $6.45 \mathrm{M} \mathrm{HCl}$. The reaction was for $3 \mathrm{~h}$ at $t=50{ }^{\circ} \mathrm{C}$. The brown solution became raspberry. After the reaction was completed, the solution evaporated at room temperature to a small volume. Then the crystals were filtered and recrystallized from $6 \mathrm{M}$ $\mathrm{HCl}$. The yield: $1.7 \mathrm{~g}$ (70\%). Found, \%: CI-44.97; N-3.55; Ru-25.64; and Li-3.52 Calculated for $\mathrm{H}_{4} \mathrm{Cl}_{8} \mathrm{Li}_{3} \mathrm{NRu}_{2} \mathrm{O}_{2}, \%: \mathrm{Cl}-45.00 ; \mathrm{N}-3.53 ; \mathrm{Ru}-25.61$; and $\mathrm{Li}-3.55$. IR spectrum, $v^{\text {as }}$ in $\mathrm{cm}^{-1}: \mathrm{Ru}^{-\mathrm{Cl}}$ 189, 285, 328; Ru-N-O 340; Ru-N 583; N-O 900.

\subsubsection{Obtaining the Binuclear Nitric Chlorido Ruthenium Complex $\mathrm{Li}_{3}\left(\mathrm{Ru}_{2}(\mu-\mathrm{N}) \mathrm{Cl}_{8} \cdot 2 \mathrm{H}_{2} \mathrm{O}\right.$}

$$
\mathrm{Li}_{2}\left(\mathrm{RuNOCl}_{5}\right) \cdot 2 \mathrm{H}_{2} \mathrm{O} \stackrel{\mathrm{SnCl}_{2} \cdot \mathrm{HCl}}{\rightarrow} \mathrm{Li}_{3}\left(\mathrm{Ru}_{2}(\mu-\mathrm{N}) \mathrm{Cl}_{8} \cdot 2 \mathrm{H}_{2} \mathrm{O}\right.
$$

In addition to the freshly prepared $\mathrm{Li}_{2}\left(\mathrm{RuNOCl}_{5}\right)$ solution $(0.00826 \mathrm{M}), \mathrm{SnCl}_{2}$ solution was added $\left(0.0219 \mathrm{M} \mathrm{SnCl}_{2} \cdot 2 \mathrm{H}_{2} \mathrm{O}\right.$ in $\left.20 \% \mathrm{HCl}\right)$. The mixture was heated when mixed for $3 \mathrm{~h}$ and $t=$ $80-90{ }^{\circ} \mathrm{C}$. The raspberry solution became red-brown. The solution was quickly cooled down in a bath (alcohol mixed with liquid nitrogen). The dropped crystals were filtered out. The substance was washed with a minimum amount of cold distilled water and then with an acetone solution (35\%) and recrystallized from $3 \mathrm{M} \mathrm{HCl}$. The yield: $1.8 \mathrm{~g}$ (50\%). Found, \%: $\mathrm{Cl}-50.93 ; \mathrm{N}-2.56 ; \mathrm{Ru}-36.28$; and $\mathrm{Li}-3.71$. Calculated, \%: $\mathrm{Cl}-50.95 ; \mathrm{N}-2.52 ; \mathrm{Ru}-36.31 ;$ and $\mathrm{Li}-3.75$. Electronic spectrum: 203 nm (ع 2.83-104 nm), 287 nm ( ع 2.08-104 nm), IR, cm ${ }^{-1}$ : Cl-Ru-Cl 220; Ru-Cl 301; Ru-N-Ru 330; and Ru-N 1075.

\subsection{Characterization of Complex 1}

\subsubsection{Elemental Analysis}

Elemental analysis was carried out at the Analytical Center of Institute of Problems of Chemical Physics RAS by CHNOS analyzer Vario EL cube (Elementar GmbH, Langenselbold, Germany), metals-by atomic absorption spectrometer «MGA-915» (Atompribor LLC, St. Petersburg, Russia).

\subsubsection{IR Spectroscopy}

IR spectra were recorded on the IR Fourier spectrometer Bruker Invenio R (Bruker Optik GmbH, Ettlingen, Germany) in the range $6000 \div 80 \mathrm{~cm}^{-1}$, the sample for analysis was prepared in the tablet $\mathrm{KBr}$.

\subsubsection{X-ray Diffraction Analysis}

X-ray diffraction analysis was performed using an Agilent XCalibur CCD-diffractometer with an EOS detector at $100 \mathrm{~K}$. The data were collected and processed, and the unit cell parameters 
were determined and refined using the CrysAlis PRO program (Agilent Technologies LTD, Yarnton, Oxfordshire, UK) [26]. In experiments, a crystal of $0.2 \mathrm{~mm} \times 0.15 \mathrm{~mm} \times 0.05 \mathrm{~mm}$ in size was used. The crystal structure was solved by the direct method followed by a series of Fourier syntheses. The positions and temperature parameters of non-hydrogen atoms were refined in the isotropic and then in the anisotropic approximation by the full-matrix least-squares method. The positions of the hydrogen atoms of a water molecule were revealed from difference syntheses and refined with restrictions on bond lengths and thermal parameters. All calculations were made using the SHELXTL 6.14 software package (Brucker, Madison, USA) [27].

\subsubsection{Spectrophotometric Research}

Specord M-40 (Carl Zeis Industrielle Messtechnik GmbH, Oberkochen, Germany) was used to register the spectrum of the complex in a quartz cuvette $(1=1 \mathrm{~cm})$.

\subsubsection{Cyclic Voltammetry}

The cyclic voltammogram was recorded on a computerized potentiostat IPC-Compact P-8 (Elins Ltd., Chernogolovka, Russia). Cyclic voltammograms of the complexes were recorded on a glass-carbon electrode, $d=5 \mathrm{~mm}$, in a sealed three-electrode cell in a nitrogen atmosphere. The auxiliary electrode was a Pt plate $\left(1 \mathrm{~cm}^{2}\right)$. All potentials given in the work were determined relative to the calomel electrode of comparison (SCE).

Potentiometric titration was carried out with the help of a compensation unit by using a polarographic analyzer EZ-7 (Laboratorni pristroje, Prague, Czech Republic). For potentiometric titration, a circuit was assembled from an indicator electrode in the sample solution and a comparison electrode. A SCE was used as a comparison electrode.

\subsection{Kinetic Measurements}

The kinetics of oxygen formation was measured on a vacuum glass device (design of the Institute of Problems of Chemical Physics of RAS). The amount of oxygen released was determined by a calibrated pressure gauge. The catalyst solution was poured into the reactor, and the cerium salt solution was poured into the side device. After preliminary degassing with freezing and thawing (3 times), the mixture was brought to the desired temperature, the solutions were mixed, and the reaction began. Using a calibrated vacuum gauge, the kinetics of oxygen evolution were monitored. At elevated temperatures, the reaction vessel was thermostated. After the reaction, gaseous products were collected in a mass spectrometer ampoule connected to the reactor. The amount of oxygen released was calculated by the formula for an ideal gas $\mu=$ PV/RT mol.

Turnover frequencies (TOFs) were defined as moles of produced product per mole of catalyst per s ${ }^{-1}$.

Turnover number (TONs) were defined as moles of produced product per mole of catalyst, $\mathrm{nO}_{2} / \mathrm{n}_{\text {cat }}$.

\section{Mass Spectrometric Method of Gaseous Products Definition}

The gaseous products of the water oxidation reaction were analyzed on a MI-1201B mass spectrometer (Selmi LLC, Sumy, Ukraine).

Chromato-mass spectrometric method:

Mass spectra of ruthenium complex solutions were obtained by ESI method on an LCMS-2020 liquid chromato-mass spectrometer (Shimadzu Corporation, Kyoto, Japan) equipped with a SIL-20 AC automatic sampler. Aqueous solutions were introduced into the electrospray ionization source using an automatic sampler at a flow rate of $20 \mu \mathrm{L} / \mathrm{min}$. The volume of injected sample ranged from 0.1 to $3 \mu \mathrm{L}$. When a voltage was applied to the capillary (from 0.5 to $4.5 \mathrm{kV}$ ), finely dispersed sputtering of the analyzed solution occurred, the final stage of which was the field evaporation of the ions contained in the sample. Some of these ions enter the mass analyzer through a vacuum interface $(\mathrm{m} / \mathrm{z}$ from 10 to 2000 are measured). As a rule, the temperature of the evaporator unit was $200{ }^{\circ} \mathrm{C}$. 
The calculated mass spectrum was obtained using the program Molecular Weight Calculator for Windows in Version 6.49 (http://www.alchemistmatt.com/, Pacific Northwest National Laboratory, Richland, USA).

\section{Results}

\subsection{Synthesis and Properties of the Binuclear Ruthenium (IV) Nitrido Chloride Complex with Lithium Counter-Cations}

For the multi-substrate concert processes, which is the OPS, the minimum distance between the transition metal ions in the catalytic center is very important. In order to obtain an effective ruthenium catalyst for the reaction of biomimetic water oxidation in PSII oxygen photosynthesis, an approach was chosen, which consisted in obtaining a ruthenium catalyst with the bridge $\mathrm{N}$ between the nuclei of $\mathrm{Ru}$. For this purpose, a binuclear ruthenium nitrido complex $\mathrm{Ru}(\mathrm{IV}) \mathrm{Li}_{3}\left(\mathrm{Ru}_{2}(\mu-\mathrm{N}) \mathrm{Cl}_{8} \cdot\left(\mathrm{H}_{2} \mathrm{O}\right)_{2}\right)(\mathbf{1})$ was synthesized.

Red crystals of Complex $\mathbf{1}$ are highly soluble in water. The obtained X-ray diffraction data for Complex 1 correspond with the X-ray diffraction analysis of a similar potassium salt [20]. According to the X-ray diffraction data, it is a binuclear centrosymmetric complex having a linear skeleton. In the crystal structure of the complex, two ruthenium atoms are connected by a nitrogen bridge. The Ru-N distance in this complex is shorter $(1.715 \AA)$ than the Ru-O distance $(1.86 \AA)$ in its oxygen counterpart $\mathrm{Li}_{4}\left(\mathrm{Ru}_{2}(\mu-\mathrm{O}) \mathrm{Cl}_{10}\right)(2)$ [23], which indicates the presence of a double bond between atoms $\mathrm{Ru}$ and $\mathrm{N}$.

In contrast to the binuclear oxocentric Complex 2, the behavior of which in solution has been studied by many authors [25], the solutions of nitride-centered Complex $\mathbf{1}$ have not been studied sufficiently. In particular, in [28], some characteristics of aqueous solutions of potassium salt are given (molar conductivity, electronic, and IR absorption spectra in the UV region). Information on the participation of similar complexes with both $\mathrm{N}$ - and O-bridges in the oxidation of water could not be found.

\subsection{Behavior of Complex $\mathbf{1}$ in Dilute Aqueous Solution}

Freshly prepared aqueous solution of the investigated Complex 1 , concentration $2 \times 10^{-3} \mathrm{M}$, was painted yellow-brown. Its electronic spectrum, shown in Figure 2, contains two intensive absorption bands in the ultraviolet region with $\lambda=203$ and $287 \mathrm{~nm}$, and less intensive bands at $\lambda=335-380$ and $\lambda=435 \mathrm{~nm}$ (not shown in Figure 2). Over time, the intensity of all the bands drops: In the first 30-60 min, a sharp drop $\varepsilon$ in all the bands is observed, and then it slows down. A day later, only a small plateau at $410-440 \mathrm{~nm}$ remains in the visible area. At the same time, all the bands gradually shift $(\approx 10 \mathrm{~nm})$ towards shorter wavelengths and the solution becomes lighter. The observed gypsum shift of absorption bands in the visible region and their decreasing intensity may be a consequence of the replacement of $\mathrm{Cl}$ ions in the internal sphere of the complex by water molecules. This assumption is plausible, because due to the short $\mathrm{Ru}-\mathrm{N}$ bond $(1.715 \AA)$ in the nitrido complex the translabilizing effect can lead to weakening of the $\mathrm{Ru}-\mathrm{Cl}$ bond.

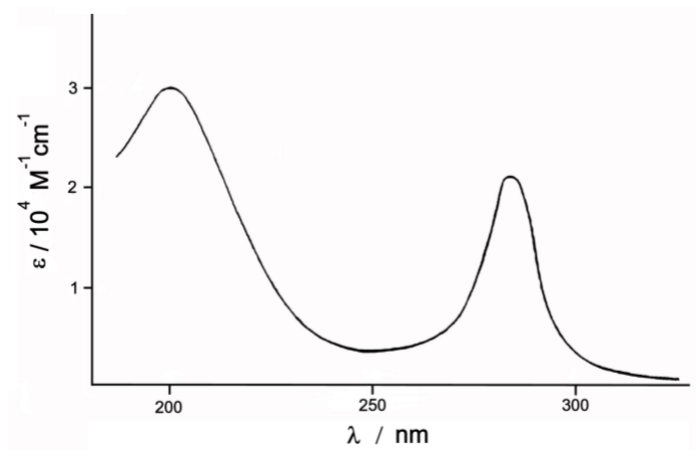

Figure 2. Electronic spectrum of Complex 1, concentration $1=2 \times 10^{-3} \mathrm{M}$. 
The $\mathrm{pH}$ value of the freshly prepared Complex $\mathbf{1}\left(2 \times 10^{-3} \mathrm{M}\right)$ is equal to 5.2 and quickly decreases during the first $40 \mathrm{~min}$, as shown in Figure 3.
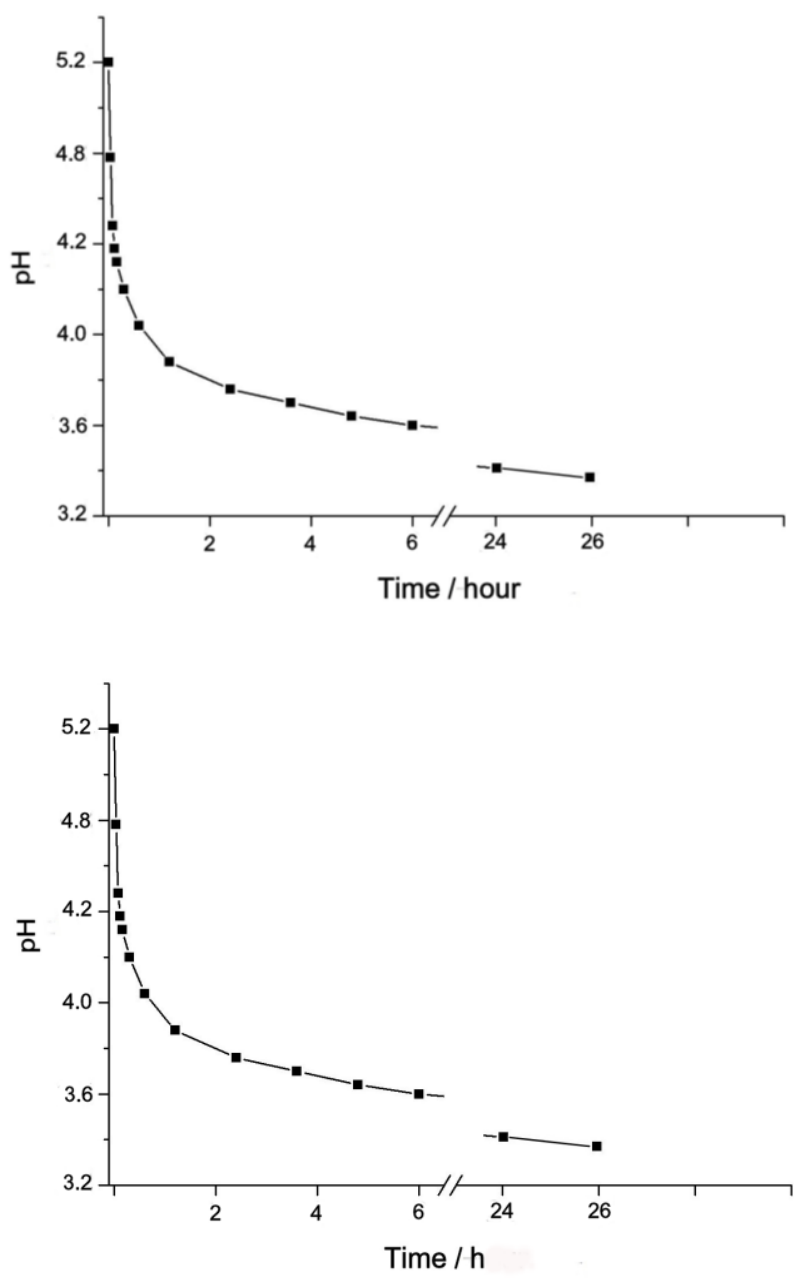

Figure 3. Change in $\mathrm{pH}$ in the aqueous solution of Complex $\mathbf{1}$ in time, concentration $1=2 \times 10^{-3} \mathrm{M}$.

At the further holding of the solution, $\mathrm{pH}$ decreases slowly, reaching 3.85 in a day, which corresponds to the concentration of ions $(\mathrm{H}+)=1.41 \times 10^{-4} \mathrm{M}$. The increase in the concentration of $\mathrm{H}^{+}$ions is due to the acid dissociation of water molecules, which replace the $\mathrm{Cl}$ ions in the internal coordination sphere of Complex 1. It follows from the above that in the diluted aqueous solution, Complex $\mathbf{1}$ is stable for about one hour, and then gradually transforms into a binuclear nitrido-aqua hydroxy-chloro-complex of ruthenium, $\left(\mathrm{Ru}_{2}{ }^{8+}(\mu-\mathrm{N})\left(\mathrm{H}_{2} \mathrm{O}\right)_{x}(\mathrm{OH})_{y} \mathrm{Cl}_{8-\mathrm{x}-\mathrm{y}}\right)^{\mathrm{n}-}$.

\subsection{Electrochemical Studies of Aqueous Solutions of the Complex 1}

The electrochemical behavior of the solution of Complex 1 is very different from the behavior of its oxygen counterpart [29]. While the binuclear Oxo-complex 2 is reduced on the platinum electrode at $\mathrm{E}=0.40 \mathrm{~V}$ [23], the binuclear nitrido Complex $\mathbf{1}$ is reduced in the region of more negative potentials (Figure 4).

On the polarogram of Complex 1 in the area of negative potentials (from 0.0 to $-1.3 \mathrm{~V}$ ), two recovery waves with $\mathrm{E}=-0.65$ and $-0.85 \mathrm{~V}$ relative to our SCE are observed.

The angular coefficient of semi-logarithmic dependence, equal to the first wave of 0.06 , is characteristic of the reversible single-electrode process [30], which indicates the recovery of one of the two ions $\mathrm{Ru}(\mathrm{IV})$ in the complex to $\mathrm{Ru}(\mathrm{III})$; that is, the formation of a mixed valence complex $\mathrm{Ru}_{2}(\mathrm{IV}, \mathrm{III})$. 
The second wave is significantly lower in height, judging by the value of the angle coefficient equal to 1.5 , and is irreversible. Perhaps it responds to some other ionic form present in the solution.

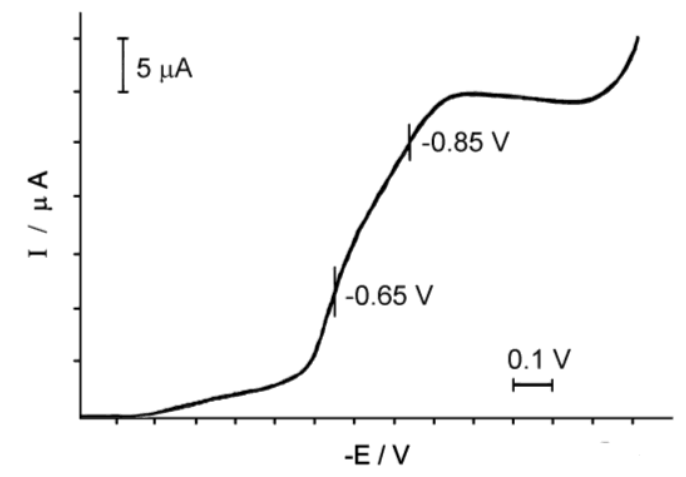

Figure 4. Polarogram of the aqueous solution of Complex $1,\left(\mathrm{Ru}_{2}\right)=2 \times 10^{-3} \mathrm{M}$, the background electrolyte is $0.1 \mathrm{M} \mathrm{NaCl}$.

In Figure 5 there is a cyclic voltammogram of the complex in the range from 1.0 to $-0.2 \mathrm{~V}$, from which it is clear that the recovery peaks of $\mathrm{Ru}(\mathrm{IV})$ are absent, and on the anode branch of the cyclic voltammogram a peak of oxidation at $\mathrm{E}=0.95-1 \mathrm{~V}$ is observed, indicating the presence in the solution of Complex 1 , along with $\mathrm{Ru}(\mathrm{IV})$ and $\mathrm{Ru}(\mathrm{III})$. The height of this peak decreases after electrooxidation at $\mathrm{E}=1.03 \mathrm{~V}$ on the Pt electrode, due to oxidation of $\mathrm{Ru}(\mathrm{III})$ to $\mathrm{Ru}(\mathrm{IV})$.

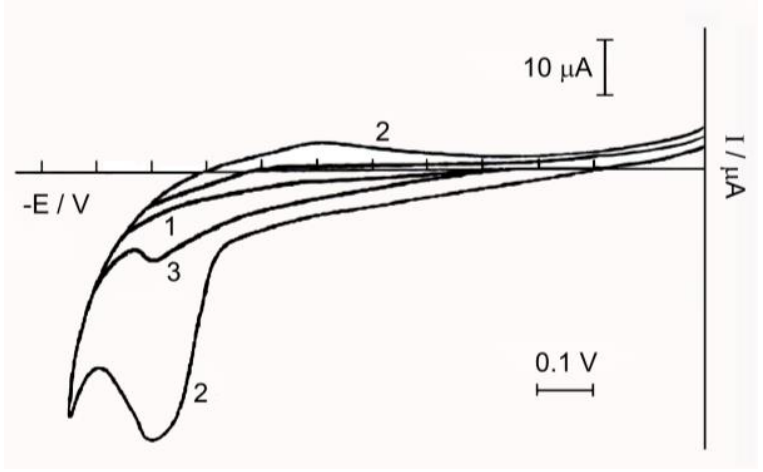

Figure 5. Cyclic voltammogram: Curve 1-background electrolyte $0.1 \mathrm{M} \mathrm{NaCl}$; Curve 2-.5 $\times$ $10^{-3} \mathrm{M}$ solution of Complex 1; Curve 3-1.5 $\times 10^{-3} \mathrm{M}$ solution of Complex $\mathbf{1}$ after oxidation on a mesh Pt-electrode.

The anode peak at the cyclic voltammogram increases with prolonged holding of the complex solution. This is probably due to the fact that there is an intra-sphere red-ox reaction between $\mathrm{Ru}(\mathrm{IV})$ and the coordinated water molecules, leading to the accumulation of $\mathrm{Ru}(\mathrm{III})$.

All these processes start immediately after the complex dissolution in water; after an hour they slow down and continue at a fading rate of more than a day. In this case, along with the initial anions $\left(\mathrm{Ru}_{2}{ }^{8+}(\mu-\mathrm{N})\left(\mathrm{H}_{2} \mathrm{O}\right)_{2} \mathrm{Cl}_{8}\right)^{3-}$ complex anions of composition $\left(\mathrm{Ru}_{2}{ }^{8+}(\mu-\mathrm{N})\left(\mathrm{H}_{2} \mathrm{O}\right)_{x}(\mathrm{OH})_{y} \mathrm{Cl}_{8-\mathrm{x}-\mathrm{y}}\right)^{\mathrm{n}-}$ are formed in aqueous solutions.

When the $\mathrm{pH}$ of the solution is $>6$, the $\mathrm{H}_{2} \mathrm{O}$ molecules are completely deprotonated, and when the $\mathrm{pH}$ is $>9$, hydroxide $\mathrm{Ru}(\mathrm{IV})$ is formed.

\subsection{The Behavior of the Complex $\mathbf{1}$ in Acidic Solution}

The possibility of decomposition of Complex $\mathbf{1}$ in acidic solutions is unlikely due to the short distance Ru-N. To confirm this assumption, we compared the IR spectra of the initially solid complex and the substance obtained by evaporation at room temperature in a rotary evaporator of its solution, 
aged for 2 days (Figure 6). The comparison of IR spectra showed that the band at $1075 \mathrm{~cm}^{-1}$, attributed to stretching vibrations of the $\mathrm{Ru}-\mathrm{N}-\mathrm{Ru}$ bonds, is present in the IR spectra of both substances, but the second band at $1049 \mathrm{~cm}^{-1}$ appears in the spectrum of the substance obtained after evaporation of the solution, which may be associated with the replacement chlorine atoms to water molecules, as indicated by some of the above methods. In the near spectral region, there are characteristic strong vibrations of the $\mathrm{Cl}-\mathrm{Ru}-\mathrm{Cl}$ bonds at $220 \mathrm{~cm}^{-1}$, as well as the $\mathrm{Ru}-\mathrm{Cl}$ band at $301 \mathrm{~cm}^{-1}$ and the $\mathrm{Ru}-\mathrm{N}$ shoulder at $330 \mathrm{~cm}^{-1}$. The stretching vibrations of the water and hydroxyl groups appear in the form of a broad band with a maximum at $3253 \mathrm{~cm}^{-1}$, and the deformation vibrations of adsorbed water in the form of a band at $1610 \mathrm{~cm}^{-1}$.

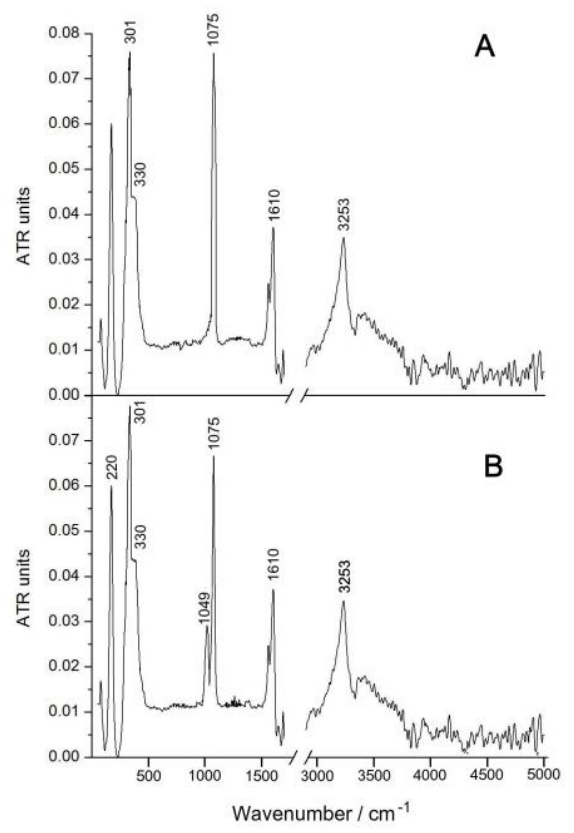

Figure 6. IR spectra (KBr) of the solid Complex $1(\mathrm{~A})$ and substance obtained after evaporation of the solution Complex $1(\mathbf{B})$.

Further research using ESI mass spectrometric analysis (Figure 7) showed that Complex 1 in an acidic environment not only preserves as the binuclear structure, but also dimerizes into a tetra-ruthenium dinitrido complex, similar to the adamantane-like $\mathrm{Ru}_{4} \mathrm{O}_{6}$ cluster (Richens complex), the structure of which was determined by EXAFS [31]. Each binuclear nitrido-chloride ruthenium complex $\mathrm{Ru}^{\mathrm{IV}} \mathrm{Ru}^{\mathrm{IV}}$ is two-electronically oxidant. But Complex $\mathbf{1}$ cannot oxidize water two-electronically to $\mathrm{H}_{2} \mathrm{O}_{2}$, because the redox potential of the $\mathrm{Ru}^{\mathrm{IV}} \mathrm{Ru}^{\mathrm{IV}} / \mathrm{Ru}^{\mathrm{III}} \mathrm{Ru}^{\mathrm{III}}$ pair $(1.24 \mathrm{~V})$ is much lower than the redox potential of the $2 \mathrm{H}_{2} \mathrm{O} / \mathrm{H}_{2} \mathrm{O}_{2}$ pair $(1.76 \mathrm{~V})$, so that the water should be oxidized by a four-electron mechanism. The initial Complex $\mathbf{1}$ is a two-electron oxidant; therefore, for the four-electron oxidation of the water molecules to an oxygen molecule, two binuclear complexes should be dimerized into a tetra-nuclear cluster. The reaction stoichiometry can be written as

$$
2\left(\mathrm{Ru}^{\mathrm{IV}} \mathrm{Ru}^{\mathrm{IV}}\right)+2 \mathrm{H}_{2} \mathrm{O}=2\left(\mathrm{Ru}^{\mathrm{III}} \mathrm{Ru}^{\mathrm{III}}\right)+\mathrm{O}_{2}+4 \mathrm{H}^{+} .
$$

Figure 7 shows the mass spectrum of the product of the reduction of the initial Complex 1 with water, in which the maximum peak with a mass of $\mathrm{m} / \mathrm{z}=512.28$ corresponds to the tetra-nuclear ruthenium cation $\mathrm{Ru}_{4} \mathrm{~N}_{2} \mathrm{O}_{5}{ }^{+}$and its isotopic distribution.

This tetra-nuclear ruthenium complex during the oxidation of water by $\mathrm{Ce}$ (IV) compounds in APS also catalyzes the four-electron oxidation of water by Reaction (3).

$$
4 \mathrm{Ce}^{4+}+2 \mathrm{H}_{2} \mathrm{O}=4 \mathrm{Ce}^{3+}+\mathrm{O}_{2}+4 \mathrm{H}^{+} .
$$




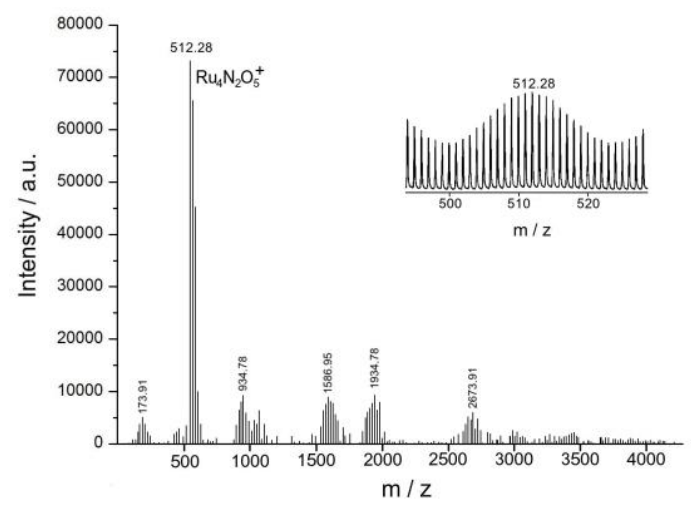

Figure 7. ESI mass spectrum of the product of the reduction of the initial Complex $1\left(10 \times 10^{-3} \mathrm{M}\right.$ in 29:70:1 $\mathrm{CH}_{3} \mathrm{CN}: \mathrm{H}_{2} \mathrm{O}: \mathrm{HCOOH}$ solvent blend).

In the catalytic process for the regeneration of $\left(\mathrm{Ru}^{\mathrm{III}} \mathrm{Ru}^{\mathrm{III}}\right)_{2}$ to its active state $\left(\mathrm{Ru}^{\mathrm{IV}} \mathrm{Ru}^{\mathrm{IV}}\right)_{2}$, it is necessary to consume four one-electron oxidizers of Ce (IV).

Of course, the collision of four cerium molecules does not occur simultaneously; sequential bimolecular reactions of stepwise oxidation of the reduced complex $\left[\mathrm{Ru}^{\mathrm{III}} \mathrm{Ru}{ }^{\mathrm{III}}\right]_{2}$ to $\left[\mathrm{Ru}^{\mathrm{IV}} \mathrm{Ru}^{\mathrm{IV}}\right]_{2}$ with its subsequent decomposition into the reduced catalyst, $\mathrm{O}_{2}$ and $4 \mathrm{H}^{+}$by Reaction (2), take place.

\subsection{Kinetic Measurements of Reaction of Water Oxidation with Exogenous Oxidizer}

The possibility of decomposition of the complex in acid solutions is unlikely due to the short distance of $\mathrm{Ru}-\mathrm{N}$. In this connection, the reaction of water oxidation with exogenous oxidizer $\left(\mathrm{NH}_{4}\right)_{2} \mathrm{Ce}\left(\mathrm{NO}_{3}\right)_{6}(\mathrm{Ce}(\mathrm{IV}))$, catalyzed by Complex 1, was studied and compared with the similar Complex 2 [23]. Counter-catione $\mathrm{Li}^{+}$in Complex $\mathbf{1}$ has a significant impact on the stability and activity of the catalyst. Kinetic curves of oxygen formation in $2.5 \mathrm{M} \mathrm{HCl}$ during biomimetic oxidation of water by an excess of Ce(IV) compounds in coordination Spheres of $\mathbf{1}$ and $\mathbf{2}$ differ (Figure 8).

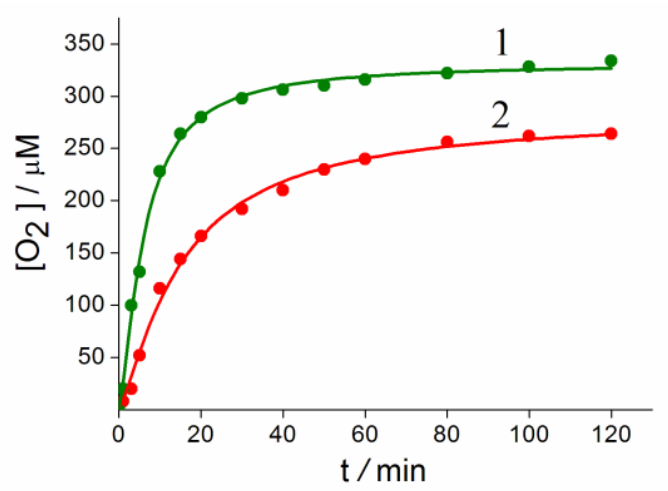

Figure 8. Kinetics of $\mathrm{O}_{2}$ formation at water oxidation by $\mathrm{Ce}(\mathrm{IV})$ compounds catalyzed by Complexes 1

(1) and 2 (2).

Conditions: 1 and $2=1.1 \times 10^{-6}$ mole, $\mathrm{CAN}=1.1 \times 10^{-4}$ mole, $22^{\circ} \mathrm{C}, 2.5 \mathrm{M} \mathrm{HCl}$.

TOF $1=0.33 \mathrm{~s}^{-1}, \mathrm{TON}=304$

TOF $2=0.12 \mathrm{~s}^{-1}, \mathrm{TON}=240$.

Analysis of the gas phase products of the reaction of water oxidation by mass spectrometric method showed that the only one product of the reaction is $\mathrm{O}_{2}(\mathrm{~m} / \mathrm{z}=32)$ (Figure 9). 


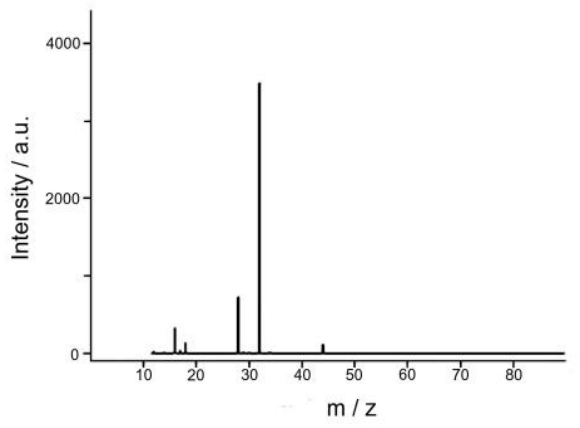

Figure 9. Mass spectrum of the gas phase products of the water oxidation reaction by Ce(IV) compounds catalyzed by Complex 1 .

From Figure 8 it can be clearly seen that Complex 1 is more active (TOF $0.33 \mathrm{~s}^{-1}$, TON 304) compared with Complex 2 (TOF $=0.12 \mathrm{~s}^{-1}, \mathrm{TON} 240$ ). The rather high activity 1 indicates the strength of the catalyst structure in comparison with other previously described systems containing organic ligands and the labile bonds $\mathrm{Ru}-\mathrm{O}-\mathrm{Ru}[6-9]$. The effect of the $\mathrm{Li}^{+}$cation is not yet clear, and it is the subject of further research.

\section{Conclusions}

In this paper, important experimental results on the synthesis and physico-chemical properties of an inorganic catalyst of biomimetic water oxidation for the APS and its use as a precursor in an acidic medium were obtained. Thus, the preparation of a lithium salt of the binuclear $\mu$-nitrido-chloride complex has opened the possibility of using it as a precursor in the oxidation of water in APS. In an acidic environment, the complex self-organizes into a tetra-nuclear cluster, which is a catalyst for the four-electron oxidation of water to form an $\mathrm{O}_{2}$ molecule. The activity of the catalyst is $\sim 3$ times higher than that of a similar complex with oxygen bridges.

Author Contributions: Z.M.D. and T.S.D. conceived and designed the experiments and T.S.D. also analyzed the data; G.V.S. performed crystallographic studies; Z.M.D., V.Y.T. and L.V.A. performed physico-chemical research; V.V.D. performed the kinetic studies; Z.M.D., L.V.A. and T.S.D. wrote the paper. All authors have read and agreed to the published version of the manuscript.

Funding: This research was carried out in the framework of the state task (No. 0089-2019-0004, AAAA-A19119071190045-0).

Conflicts of Interest: The authors declare no conflict of interest. The funders had no role in the design of the study; in the collection, analyses, or interpretation of data; in the writing of the manuscript, or in the decision to publish the results.

\section{References}

1. Umena, Y.; Kawakami, K.; Shen, Y.R.; Kamiya, M. Crystal structure of oxygen-evolving photosystem II at a resolution of $1.9 \AA$ A Nature 2011, 473, 55-60. [CrossRef]

2. Dzhabiev, T.S.; Shilov, A.E. Biomimetic utilization of solar energy. Russ. Chem. Rev. 2012, 12, 1146-1158. [CrossRef]

3. Kärkäs, M.D.; Verho, O.; Johnston, E.V.; Âkermark, B. Artificial photosynthesis: Molecular systems for catalytic water oxidation. Chem. Rev. 2014, 114, 11863-12001. [CrossRef]

4. Dzhabiev, T.S.; Shafirovich, V.Y.; Shilov, A.E. Kinetics of oxidation of water by Mn(iv)sulfate in acid-media. React. Kinet. Catal. Let. 1976, 4, 11-18. [CrossRef]

5. Dzhabiev, T.S.; Denisov, N.N.; Moiseev, D.N.; Shilov, A.E. Multielectron oxidation of water in a chemical model of the active center of photosystem II of natural photosynthesis. Dokl. Biochem. Biophys. 2004, 396, 151-153. [CrossRef] [PubMed]

6. Hurst, J.K. Chemistry in pursuit of water oxidation catalysts for solar fuel production. Science 2010, 328, 315-316. [CrossRef] [PubMed] 
7. Gersten, S.W.; Samuels, G.J.; Meyer, T.J. Catalytic-oxidation of water by an oxo-bridged ruthenium dimer. J. Am. Chem. Soc. 1982, 104, 4029-4030. [CrossRef]

8. Yagi, M.; Kaneko, M. Molecular catalysts for water oxidation. Chem. Rev. 2001, 101, 21-35. [CrossRef] [PubMed]

9. Sens, C.; Romero, I.; Rodriguez, M.; Llobet, A.; Parella, T.; Benet-Buchholz, J. A new Ru complex capable of catalytically oxidizing water to molecular dioxygen. J. Am. Chem. Soc. 2004, 126, 7798-7799. [CrossRef]

10. Suess-Fink, G. Water oxidation: A robust all-inorganic catalyst. Angew. Chem. Int. Ed. 2008, 47, 5888-5890. [CrossRef]

11. Sartorel, A.; Carraro, M.; Scorrano, G.; De Zorzi, R.; Geremia, S.; McDaniel, N.D.; Bernhard, S.; Bonchio, M. Polyoxometalate embedding of a tetraruthenium(IV)-oxo-core by template-directed metalation of [gamma-SIW10O36](8-): A totally inorganic oxygen-evolving catalyst. J. Am. Chem. Soc. 2008, 130, 5006-5007. [CrossRef] [PubMed]

12. Geletii, Y.V.; Botar, B.; Koegerler, P.; Hillesheim, D.A.; Musaev, D.G.; Hill, C.L. An all-inorganic, stable, and highly active tetraruthenium homogeneous catalyst for water oxidation. Angew. Chem. Int. Ed. 2008, 47, 3896-3899. [CrossRef] [PubMed]

13. Geletii, Y.V.; Huang, Z.; Hou, Y.; Musaev, D.G.; Lian, T.; Hill, C.L. Homogeneous light-driven water oxidation catalyzed by a tetraruthenium complex with all inorganic ligands. J. Am. Chem. Soc. 2009, 131, 7522-7523. [CrossRef]

14. Cao, R.; Ma, H.; Geletii, Y.V.; Hardcastle, K.I.; Hill, C.L. Structurally characterized Iridium(III)-containing polytungstate and catalytic water oxidation activity. Inorg. Chem. 2009, 48, 5596-5598. [CrossRef] [PubMed]

15. Sala, X.; Romero, I.; Rodriguez, M.; Escriche, L.; Llobet, A. Molecular catalysts that oxidize water to dioxygen. Angew. Chem. Int. Ed. 2009, 48, 2842-2852. [CrossRef] [PubMed]

16. Huang, Z.; Luo, Z.; Geletii, Y.V.; Vickers, J.W.; Yin, Q.; Wu, D.; Hou, Y.; Ding, Y.; Song, J.; Musaev, D.G.; et al. Efficient light-driven carbon-free cobalt-based molecular catalyst for water oxidation. J. Am. Chem. Soc. 2011, 133, 2068-2071. [CrossRef]

17. Yin, Q.; Tan, J.M.; Besson, C.; Geletii, Y.V.; Musaev, D.G.; Kuznetsov, A.E.; Luo, Z.; Hardcastle, K.I.; Hill, C.L. A fast soluble carbon-free molecular water oxidation catalyst based on abundant metals. Science 2010, 328, 342-345. [CrossRef]

18. Besson, C.; Huang, Z.; Geletii, Y.V.; Lense, S.; Hardcastle, K.I.; Musaev, D.G.; Lian, T.; Proust, A.; Hill, C.L. Cs-9[(gamma-PW $\left.\left.{ }_{10} \mathrm{O}_{36}\right)(2) \mathrm{Ru}_{4} \mathrm{O}_{5}(\mathrm{OH})\left(\mathrm{H}_{2} \mathrm{O}\right)(4)\right]$, a new all-inorganic, soluble catalyst for the efficient visible-light-driven oxidation of water. Chem. Commun. 2010, 46, 2784-2786. [CrossRef]

19. Hurst, J.K. Water oxidation catalyzed by dimeric mu-oxo bridged ruthenium diimine complexes. Coord. Chem. Rev. 2005, 249, 313-328. [CrossRef]

20. Ciehanovich, M.; Skapski, A.C. Crystal structure of potassium $\mu$-nitrido-bis[aquotetrachlororuthenate(IV)]. J. Chem. Soc. A 1971, 1792-1794. [CrossRef]

21. Cleare, B.M.; Griffith, W.P. Binuclear nitrido-complexes of ruthenium. Chem. Commun. 1969, 1302. [CrossRef]

22. Mukaida, M. The ruthenium complexes formed by the reactions of nitrosylruthenium(III) with Tin(II) in hydrochloric acid solution. Bull. Chem. Soc. Jpn. 1970, 43, 3805-3813. [CrossRef]

23. Dzhabieva, Z.M.; Shilov, G.V.; Tkachenko, V.Y.; Avdeeva, L.V.; Dzhabiev, T.S. Synthesis and structural organization of ruthenium(IV) cluster $\mathrm{Li}_{8} \mathrm{Ru}_{2} \mathrm{OCl}_{14}$ and its catalytic properties in the water oxidation reaction. Russ. J. Inorg. Chem. 2016, 61, 688-694. [CrossRef]

24. Dzhabieva, Z.M.; Tkachenko, V.Y.; Dzhabiev, T.S. Photostimulated oxidation of water catalyzed by a tetranuclear ruthenium complex with lithium countercations. High Energy Chem. 2017, 51, 215-218. [CrossRef]

25. Seddon, E.; Sedeon, K. The Chemistry of Ruthenium; Elsevier: Amsterdam, The Netherlands, 1984; p. 1373.

26. Crys Alis PRO; Agilent Technologies LTD: Yarnton, Oxfordshire, UK, 2011.

27. Sheldrick, G.M. SHELXTL: Structure Determination Software Suite; v.6.14; Brucker: Madison, WI, USA, 2000.

28. Cleare, M.J.; Griffith, W.P. Polynuclear nitrido-complexes of osmium, ruthenium, and iridium. J. Chem. Soc. A 1970, 7, 1117-1125. [CrossRef]

29. Potts, L.; Swofford, V. Mechanism of reduction of dimeric ruthenium(IV) in hydrochloric-acid solutions. Analyt. Chem. 1975, 47, 131-141. [CrossRef] 
30. Heyrovsky, Y.; Kuta, Y. Fundamentals of Polarography; MIR: Moscow, Russia, 1965; p. 559.

31. Osman, J.R.; Crayston, J.A.; Richens, D.T. Structure of tetrameric aqua ruthenium(IV): An investigation by ruthenium K Edge EXAFS. Inorg. Chem. 1998, 37, 1665-1668. [CrossRef]

(C) 2020 by the authors. Licensee MDPI, Basel, Switzerland. This article is an open access article distributed under the terms and conditions of the Creative Commons Attribution (CC BY) license (http://creativecommons.org/licenses/by/4.0/). 